\title{
A Study on the Performance of Regional Rural Banks in India
}

\author{
${ }^{1}$ Dr Anjum Mehtab Kathawala and ${ }^{* 2}$ Vinod Sharma
}

${ }^{1}$ Assistant Professor, Department of Accountancy and Business Statistic, Bhupal Nobles University, Udaipur ${ }^{2}$ Research Scholar, Bhupal Nobles University, Udaipur

\begin{abstract}
Banking plays a vital role in the growth and development of developing countries like India. Banks lubricate the entire monetary and financial system and ensure smooth operations. Nearly $70 \%$ of the total of Indian population lives in rural areas. For the development of Indian economy, there is a need for the development of the rural areas. For the purpose of rural development, there is a need for the banking system in rural areas which provide credit at lower and at reasonable terms to the rural households unlike traditional moneylenders which exploit the rural people by providing loans at a very high interest rate which leads to rural people were unable to repay loans given by moneylenders and lost everything and also commit suicide. To avoid all those negative consequences, the government appoints a working group on rural credit, the narasimban committee. On the basis of recommendations given by the narasimban committee, regional rural banks were established. The main objective behind the establishment of these banks is the development of agriculture, trade, commerce, industry and other productive activities in the rural areas particularly in those areas where banking services does not exist and make available cheaper institutional credit to the weaker sections of the society. This research paper throws light on the need of banking system in rural areas and significant role played by banking system in the development of rural areas and discusses about the problem faced by regional rural banks in India and suggestions to overcome the problems. The main aim of this paper is to analyse the present level of financial performance of RRBs in India as on 31st march 2017 in comparison to 31st march 2016. This study is based on the secondary data collected from the annual reports of $N A B A R D$. This study finds and concludes that the RRBs play a very important role in the development of rural areas.
\end{abstract}

Keywords: Regional rural banks, rural development, Credit facilities, banking

\section{Article Publication}

Published Online: $12-\mathrm{Nov}-2021$

*Author's Correspondence

8 Vinod Sharma

9 Research Scholar, Bhupal Nobles University, Udaipur

$\triangle$ vinodsharma.205@gmail.com

\section{$\underline{10.31305 / \text { rrijm.2021.v06.i11.005 }}$}

C 2021The Authors. Published by RESEARCH REVIEW International Journal of Multidisciplinary. This is an open access article under the CC BY-

\section{NC-ND license (c)}

(https://creativecommons.org/licenses/ by-nc-nd/4.0/)

\section{Introduction}

According to the census of India 2011 out of the 121 crore Indians, 83.3 crore lives in rural areas while 37.7 crores stay in urban areas. The rural- urban distribution is $68.84 \%$ and $31.16 \%$ respectively, Registrar general of India and census commissioner $\mathrm{c}$ chandramouli said. From the rural-urban distribution, it is cleared that for development of Indian economy, there is a need for rural development. Rural development is the process of improving the quality of life and economic well being of the people living in the rural areas. For rural development, there is a need for proper credit facilities. Rural households need access to financial institutions that can provide them with credit at lower rates and at reasonable rates than the traditional moneylenders who provides loans at very high interest rate and on their own terms. Due to high interest rates, rural households unable to repay loans and under that pressure there was trend of committing suicides. To meet the gap that existed in meeting the credit needs of rural poor, the govt. appointed a working group on rural credit, the narasimhan committee in July 1975. Based on its recommendations, regional rural banks emerged in 1975. These banks were meant to take banking to the rural masses, particularly in areas without banking facilities, make available cheaper institutional credit to the weaker sections of the society, mobilise rural savings and channelize them for other productive activities in rural areas and bring down the cost of providing credit in rural areas. 


\section{Literature Review}

1. Jagan Mohan (2011) in his research article concludes that the financial sector reforms without social and rural sensitivity would only aggravate the complexities of agrarian sector reforms, which are yet to take shape. It is thus hoped that the Advisory Committee, being constituted by the RBI, will be a HighPowered one suggest innovative measures with a definite roadmap to meet the emerging challenges in rural credit.

2. S. Suresha \& H. R. Uma (2011) - Financial institutions have been established to promote developmental activities in the country, and India is no exception to this. And regional rural banks (RRBs) are one of its kind. The Main objectives of RRBs are to mobilize financial resources for rural and semi-urban areas. Which are relatively poor, particularly in recent years when the government is adopting several development programs for the inclusive growth of poor rural people, the role of RRBs highlighted as very significant. This work is an effort towards evaluating the performance of such RRBs in Ramanagara district.

3. Girish.K.Nair and Dr.R.Thirumal (2012) - The RRBs should lay greater emphasis and continue with its efforts on directed credit, regulated interest rate structure and focus on profitability. Bringing in transparency in the bank's balance sheet, preparing itself to face competition and effective use of managerial resources will enhance the performance of RRBs. In the wake of economic liberalization now underway in India, the banking sector in general, and Regional Rural Banks in particular are experiencing sweeping changes. Although RRBs have played a predominant role in supplementing the efforts of the Government in eradicating poverty by dispensing credit under Government sponsored programmes, the erosion in profitability and the poor sustainability is causing much concern. The structural consolidation of RRBs has resulted in the formation of new RRBs, which are financially stronger and bigger in size in terms of business volume and outreach. This will enable them to take advantages of the economies of scale and reduce their operational costs. With the advantage of local feel and familiarity, RRBs should capitalize on better position to achieve the objectives of rural development and financial inclusion.

4. Sharma Neeraja (2010) in published research article concludes that the Regional Rural Banks (RRBs) have been growing their importance since inception, in 1975 as special institutions playing a catalyst role in the development of rural areas they have been playing a significant role in financing the weaker sections of the community in the rural areas. Regional Rural Banks are not being able to provide the desired outcome as of nonperforming assets play a negative role and steps should be taken to remove them. Economic viability should be integral part of the organizational setup. Multi agency rural credit delivery structure must be protected and supported by the Government. Competent authorities / bodies should be incorporated to float the desired knowledge / awareness about banking among the rural society which could help in increasing the assets base of RRBs through deposits. Required supports should be provided by NABARD to RRBs, pertaining to micro financing.

5. Dhaliwal N K (2010) - Regional Rural Banks were set up in 1975 with the basic objective of providing credit facilities to the rural poor. In the light of changes that have taken place in response to the financial sector reforms, the present study appratises the growth and performance of Regional the growth and performance of Regional Rural Banks in the state of Punjab. It attempts to intensively examine and compare the various aspects of growth, profitability and productivity of RRBs operating in the State and assesses the perception of customers regarding working of these institutions. The study covers all the Regional Rural Banks operating in Punjab, serving 15 districts of the State and having 210 branches. The study is based on both primary data and secondary data.

\section{Objectives of the Study}

- To study the need of banking in rural areas

- To study the functions of regional rural banks in the rural development

- To study the financial performance of regional rural banks 
- To study the challenges faced by the banking in rural areas

- To study the possible solutions of the problems faced by the rural banks in the rural areas

\section{Research Methodology}

This paper is based on the secondary data and drained from annual reports of NABARD and from various articles, reports, and websites.

\section{Need for Banking in Rural Sector}

About $70 \%$ of Indian population lives in the villages during 1970s. The savings and cash flows of the majority of the rural population is small due to which for the basic needs like food, housing, education rural households rely on credit. Most of the peoples in rural areas involve in agricultural activities. Rural households also needs funds for carrying out their agricultural activities. For meeting credit needs they approach to moneylenders because loan from the financial institutions involves a lot of paper work, formalities and also time consuming. Moneylenders take advantage of the situation and charge high interest rates. As a result of which rural peoples suffers from a great deal of indebtness. Rural peoples need financial institutions that can provides loans to them at lower rates and easy terms. To meet the credit needs of rural peoples, government appointed a working group on rural credit, the narasimhan committee in July 1975. Based on its recommendation, regional rural banks emerged in 1975. The main aim of establishment of RRBs is that rural peoples can get loans at very low rate and on easy terms. In 1975, five RRBs were established which increases to 56 in number covering 680 notified districts in 27 states and the union territory of pudcherry with a network of 21,422 branches.

\section{Objectives and Functions of Regional Rural Banks}

The main aim or idea of establishing RRB is to meet credit needs of rural people. There are some other objectives of RRBs are

1. To provide advances to small \& marginal farmers, agricultural labourers \& small entrepreneurs who are engaged in agricultural business.

2. To provide banking facilities to rural areas specially unbanked area.

3. To provide loan facilities to Cooperative societies, which are engaged on services related to rural area including agriculture activities.

4. To increase the golden opportunities of employment in RRBs which creates employment at their door step for rural people.

5. Some other auxiliary functions of RRBs * To convert the rural savings (by accepting deposits) into the productive activities in rural areas by Using that money in agricultural activities. ${ }^{*}$ Now a day's RRBs starts providing loans for purchasing durable goods against the security of gold, NSC etc

RRB's play the important role in developing the weaker section in rural areas, of our society along with this RRB's faced serious problems. The Dantwala committee, kelkar committee \& khusro committee pointed out some weakness which is faced by RRB's.

1. Huge branch expansion As at the early stage of RRB's evaluation a large network of branches opened which creates problem of overhead cost without contributing the amt. of profit. In some areas where RRB's are required, they faced difficulty to get full accommodations or facilities for housing the branches.

2. Rigid norms Rules \& regulation related with the RRB's are issued by RBI are rigid are nature and are based on all India being but it's not working because of disparity of India state by state not give the same result to another state.

3. Not viable RRB's are not able to get the same amount of profit ad other banks earns. Due to providing facility to weaker section (low interest rate $\&$ high operating cost in providing loans).

4. High cost of loan With comparison to the commercial bank, RRB's have the high long transitions costs than the commercial banks due to the low amount of loan. 
5. Problem in deposit mobilisation As RRB's deals with the weaker section of rural area, there is no huge amount of funds in bank. The weaker section is the main target of RRB's are poor. So they don't save so much money in RRB's. It provides less amount of collection in banks.

6. No proper Recruitment policy As RRB's are rural oriented they are expected to recruit staff only locally. But with the transfer of recruitment on RRB's to banking services recruitment boards, all the candidate outside the area of cooperation of RRB's eligible for RRB's . This is against the concept of RRB's.

\section{Suggestions to Improve Regional Rural Banks Working}

To improve the RRB's some parties take initiative for this and provide some solutions to the problems.

1. The important thing for existence there is the requirement of feasibility and viability of the organisation. For this there is the recommendation that RRB's should be merged with commercial banks. It will help to reduce the accumulated losses of insolvency of the banks. This solution is helpful for some RRB's only.

2. Mobilisation of funds or converting the savings of rural people in productive activity can be removed by using the funds transfer from urban to rural area with the help of govt. policies. State govt. about permit the Panchayat \& other quasi govt. to keep their funds with RRB's in that area.

3. To reduce the cost of RRB's state govt . either reorganize agricultural credit societies on establish other societies through which RRB's increase their production credit on large scale and use the economies of scale in efficient manner. Another way to reduce the cost of loan is to reduce transaction cost of providing loan to the rural people.

4. The recruitment process in RRB's should be streamlined. There should be preference to the local people and also provide proper training about the work to employees. And also there should be uniform pay scale for employees.

5. To handle with the problem of huge expansion of branches, there should be expansion of no. of employees to handle the work load. And for supervision on the RRB'S there should be the proper authority that manage and control the working of RRB'. One another method for effective working is to reduce the commercial bank branches in the rural area and hand over these branches to RRB's.

6. The main issue related with the banking system is rigid norms, there is less flexibility in the regulation system which can make the huge hindrance I'm the working of RRB's. To overcome with this problem there should be some free hand for RRB's. Some concession should be given to RRB's according to the area side or department wise according to the need of the RRB. Because at present rules are made by the authority for whole India without differentiation about the state.

\section{Conclusion}

For the purpose of rural development and meeting the credit needs of rural people, RRB came into existence on the basis of the recommendation of Narashimhan committee. The regional rural banks have been highly successful in the mobilising rural savings. RRBs are providing loans to small and marginal farmers, artisans, selfemployed persons etc. RRBs recruit local persons which creates the employment at the door steps of the rural peoples. Out of 56 RRBs 49 RRBS earning profits. To improve the functioning of RRBs Union cabinet approved extension of scheme of recapitalization of RRBs up to 2019-20. This will enable RRBs to maintain minimum prescribed capital to risk weighted asset ratio (CRAR) of 9\%. It will help RRBs in ensuring strong capital structure and minimum required level of CRAR. It will also helps in financial stability of RRBs and helps it to plays greater role in financial inclusion and meeting the credit requirements of rural areas.

\section{References}

http://www.microeconomicsnotes.com/banking/project-report-on-regional-rural-banks-rrbs/1760

https://currentaffairs.gktoday.in/tags/regional-rural-banks 
https://www.nabard.org/financialreport.aspx?cid=505\&id=24 Burgess, Robin, and Rohini Pande. "Do rural banks matter?

Evidence from the Indian social banking experiment." American Economic Review 95.3 (2005): 780-795. Varman, Mahendra. "Impact of self-help groups on formal banking habits." Economic and Political Weekly (2005): 17051713.

Matunhu, Jephias, and Stephen Mago. "Rural banking for rural development in Zimbabwe." Studies of Tribes and Tribals11.1 (2013): 43- 48.

Ghouse, Syed Mahammad, and Narayana Reddy. "Indian Regional Rural Banks Growth and Performance." National Conference on Marketing and Sustainable Development October. Vol. 13. 2017. 